\title{
Phenomenology of depression: Contributions of Minkowski, Binswanger, Tellenbach and Tatossian
}

\author{
Fenomenologia da depressão: as contribuições \\ de Minkowski, Binswanger, \\ Tellenbach e Tatossian
}

\author{
Lucas BLOC $1,2,3$ \\ Camila SOUZA ${ }^{4}$ \\ Virginia MOREIRA ${ }^{1}$
}

\begin{abstract}
Eugène Minkowski, Ludwig Binswanger, Hubertus Tellenbach and Arthur Tatossian are key authors in phenomenological psychopathology. Through a theoretical review of the main works of these authors, we shall discuss their contributions to the understanding of the lived depressed. Following a phenomenological-structural method, Minkowski developed a descriptive phenomenology of depression, focusing on lived time. Binswanger, focusing on temporality, searches for the genesis of the lived depressed through the operating modes of retrospection and melancholic prospection. Tellenbach presents the typus melancholicus, a concept associated with the notion of endon. Tatossian discusses the possible conditions for the lived depressed through phenomenological categories of time, body, space and the relationship with each other, developing the notion of depressiveness. We may conclude that, although these authors have different contributions, their ideas are similar as they adopt a phenomenological approach, a return to the lived experience, to understand its meanings.
\end{abstract}

Keywords: Depression; Phenomenology; Psychopathology.

\section{Resumo}

Eugène Minkowski, Ludwig Binswanger, Hubertus Tellenbach e Arthur Tatossian são grandes nomes da psicopatologia fenomenológica. Através de uma revisão teórica das principais obras desses autores, são discutidas as suas contribuições para a compreensão do vivido depressivo. Com um método fenômeno-estrutural, Minkowski desenvolve uma

1 Universidade de Fortaleza, Programa de Pós-Graduação em Psicologia, Laboratório de Psicopatologia e Clínica Humanista Fenomenológica. Av. Washington Soares, 1321, Edson Queiroz, 60811-905, Fortaleza, CE, Brasil. Correspondência para/Correspondence to: L. BLOC. E-mail: <lucasbloc@yahoo.com.br>.

${ }^{2}$ Université Paris Diderot, École Doctorale Recherches en Psychanalyse et Psychopathologie, Centre de Recherches Psychanalyse, Medicine et Société. Paris, France.

3 Grantee of a full Capes scholarship abroad (Process n ${ }^{\circ}$ 0998/14-1).

${ }^{4}$ Faculdade Maurício de Nassau, Curso de Psicologia. Fortaleza, CE, Brasil. 
fenomenologia descritiva da depressão, tendo como foco o tempo vivido. Binswanger, também a partir da temporalidade, busca a gênese do vivido depressivo através dos modos de funcionamento da retrospeç̧ão e da prospecção melancólica. Tellenbach apresenta o typus melancholicus, concepção atrelada à noção de endon. E Tatossian discute as condições de possibilidade do vivido depressivo através das categorias fenomenológicas do tempo, do corpo, do espaço e da relação com o outro, desenvolvendo também a noção de depressividade. Conclui-se que, apesar desses autores apresentarem diferentes contribuições, suas ideias se aproximam, pelo caráter fenomenológico que assumem, de um movimento de retorno à experiência vivida, visando compreender os seus significados.

Palavras-chave: Depressão; Fenomenologia; Psicopatologia.

According to the World Health Organization (WHO), depression is among the leading causes of disability. By the year 2030, the WHO predicts that depression will be the most common disease in the world, contributing significantly to global morbidity, as it affects more than 350 million people of all ages and in all communities, being characterized as a serious health problem (WHO, 2012). Currently, psychiatric diagnosis of depression occurs through standardized procedures using the following instruments: Diagnostic and Statistical Manual of Mental Disorders (DSM-V) and the International Classification of Diseases (ICD-10). These procedures follow a symptomatic logic and establish a series of criteria for diagnosis. These instruments have a descriptive and classificatory nature in which the possible conditions for the lived depression are not included.

Psychopathology as a specific field of study became known in 1913 with the publication of "General Psychopathology", written by the psychiatrist Karl Jaspers (Moreira, 2002; Rodrigues, 2005). Jaspers conducted a study on subjective experience in an endeavor to find the essence of pathology (Pessoti, 2006; Schneider, 2009). By introducing Husserl's phenomenology as an exclusive descriptive method in his work and not excluding the medical-scientific discourse, Jaspers is not considered the founder of phenomenological psychopathology, which does not reduce his importance and pioneering. His merit lies in having used phenomenology as a research method, opening the door to the further development of the principles of phenomenological psychopathology developed by Minkowski and Binswanger (Moreira, 2011; Pessotti, 2006; Tatossian, 1979/2006). In addition, Jaspers himself (1913/1987) considered that the phenomenological method was only one among several possible methods in psychopathology.

The phenomenological tradition in psychopathology, based on Husserl's and Heidegger's philosophy, provides clues for an understanding of man's existence, in contrast to psychiatric classification systems (Pessotti, 2006; Schneider, 2009). It emphasizes how the phenomenon presents itself and its meaning for whom experiences it, providing an understanding of the various forms of illness and its possible conditions. This is an approach that is divorced from the dominant standards of health and illness, normal and pathological, having a significant critical potential.

Discussions about depression occupy a prominent place since the development of phenomenological psychopathology, which requires the qualification of the term. Depression and melancholy are not exact expressions for the same phenomenon, although there are similarities. In this article, we chose to maintain a faithful translation of the terms used by the authors, seeking to clarify the meaning and the historical context in which they were coined. In view of the scope and contemporariness of the term depression, we decided to use it as a broad and general reference to introduce the phenomenology of depression. By the term depression, we mean intense suffering that includes a melancholic mood. Whereas the term melancholy, widely used in traditional phenomenological psychopathology, denotes specificity and a more severe depressive episode, as characterized by Tatossian (1979/2006, 1983), often associated with psychosis and discussed as one of the cycles of bipolar disorder (Binswanger, 1960/2005; Moreira \& Bloc, 2012). 
The aim of this article is to present the main contributions of Eugène Minkowski, Ludwig Binswanger, Hubertus Tellenbach and Arthur Tatossian to understand the depressive phenomenon as their publications are an important contribution from the perspective of phenomenological psychopathology. For this purpose, we conducted a theoretical review of the main works of these authors and commentators, highlighting their contributions, similarities and differences.

\section{Eugène Minkowski and descriptive phenomenology of depression}

Eugène Minkowski was born and raised in St. Petersburg, into a Jewish family, in 1885. With medical and psychiatric training, he acquired the title of Doctor of Medicine in Munich, where he also began studies in the field of philosophy (Pélicier, 1995). He developed work in the field of psychiatry and, being strongly influenced by Bergson, of whom he was a student, and Husserl (Abreu \& Silva, 2004) he developed a phenomenological view of mental illness.

Minkowski realized that psychopathological disorders were not an overlap of symptoms, but the deep expression of a modification of the entire existence of the subject. He developed a psychopathology based on ontology rather than anthropology of mental illness (Abreu \& Silva, 2004; Pélicier, 1995). In depressive disorders, the fundamental phenomenon that organizes existence is related to temporality and the symptoms present in melancholic depression must be understood based on that experience:

The melancholic do not experience time 'as propulsive energy', but feel it as a flow of temporal current. Thus, for these patients, the future is perceived as blocked; their attention is directed to the past and the present feels stagnant (Cardinalli, 2012, p.30).

This is the core of the work of Minkowski (1933/1995), in which the experience of fluid, continuous and interwoven time is an essential phenomenon for the existence of health. When temporal fluidity is inhibited, the becoming ruptures and propulsion for the future dissolves, thereby creating existential stiffness that blocks future possibilities because all the energy and perspective of the subject is focused on the inevitable episode. The distortion of the future prevents the creative impulse coming from the present time.

The work of Minkowski introduced an innovative view of psychopathology in the French psychiatric scenario. A phenomenological-structural method was proposed, in contrast with the reductionist tendency in an objectivist view of psychic phenomena. His method was intended to approach and encounter the human being, which enabled him to abandon a merely descriptive approach of the experienced phenomenon to relate it to the structure that organizes it in a dynamic mental background, in agreement with the proposal of a pathological psychology in which the pathic element corresponds to the real object of study in psychopathology (Pereira, 2000).

Understanding the pathology as pathos is to reaffirm the "original disposition of the subject which is the basis of humanity itself. Thus, pathos comprehends the entire human dimension, permeating the whole universe of the being" (Martins, 1999, p.66). Pathology is not what science defines as a disease, immersed in a negative connotation and associated with the concept of healing, but rather it corresponds to a disposition and a movement of fundamental phenomenon that comprises the existence of man and constitutes a new form of being (Martins, 1999; Pereira, 2000). The understanding of depression by means of stiffness of fluidity of becoming goes beyond the causal origin of illness, seeking to understand the meaning of the lived experience of the patient. Minkowski (1933/1995) prioritized clinical experience and patient interaction, understanding implied depressive disorder with fluidity and the movement of becoming.

Minkowski's contribution is essential and his studies point out his concern with the phenomenon experienced by the depressed and not only with the substance of depression. This idea is completely retrieved by the tradition of phenomenological 
psychopathology in that it aims to provide clinical treatment that is based on more than methodological theories, but about and based on experience.

\section{Ludwig Binswanger and temporal constitution of the lived melancholic}

Ludwig Binswanger was born in Kreuzlingen, Switzerland, in 1881 . He is considered the most distinguished of the phenomenological psychopathologists and psychiatrists. His lecture entitled "Sur la Phénoménologie", present in the book "Introduction à I'analyse existentielle", along with the famous work presented by Minkowski "Étude et analyse psychologique phénoménologique d'un cas mélancolie schizophrénique" are considered the starting point of phenomenological psychopathology (Tatossian, 1979/2006). Both works were presented on November 25, 1922, at the $63^{\text {rd }}$ session of the Swiss Society of Psychiatry in Zurich. Binswanger is recognized for having developed a new method for understanding the mentally ill while developing the existential analysis or Daseinsanalyze. His merit was to introduce philosophical and phenomenological knowledge into his theoretical framework and psychiatric practice, participating in the movement that questioned psychiatric practices at the time, which was the result of his long career at the clinic in Bellevue (Fédida, 1970; Huygens, 2011; Lehfeld, 2011). Influenced by psychoanalysis early in his career, Binswanger distanced himself from this perspective when he studied phenomenology. Most of his phenomenological works are deeply based on the movement that begins with the philosophical phenomenology of Husserl, particularly its descriptive nature. Then, through the work of Heidegger, particularly after reading "Being and Time", he then returns to Husserl's phenomenology - no longer descriptive, but a phenomenology of subjectivity, the transcendental Ego in Husserl -, in search for the constitution of the different forms of illnesses, especially melancholia, mania and delirium (Pita \& Moreira, 2013; Tatossian, 1979/2006). Later, in 1960 and discusses, through temporality, the modes of melancholia.

In discussing the lived time, Binswanger (1960/2005) understands that the past, the present and the future are temporal domains comprising retention, presentation and protention, terms used and recognized by Husserl as "constitutive structural moments of the temporal objects" (p.31). To understand these constitutive moments, Binswanger (1960/2005) cites the example of the speaker, as interpreted by Szilasi in a text on the phenomenology of Husserl. When a speaker speaks, that is, at the time of presentation, protention allows the talk, without which the sentence cannot be completed. Similarly, throughout presentation, retentions need to exist, for they are the ones that allow the speaker to know what will be expressed. One can see that in a healthy functioning individual, there is an interweaving of these elements that constitute time.

To understand melancholia, the goal would be to unveil the deficient modes of these three domains and their interaction. The melancholic temporality, as Binswanger (1960/2005) thought, is woven into two ways that he considers to be canonical to melancholia: retrospection and prospection. With relaxation of the connection between the three structural domains of time, there is a defective restructuring that absurdly connects retention and protention, which merge the past and the future. That is, with relaxation of intentional threads connecting these domains, presentation seems to become loose, empty and makes experience of the present empty.

Melancholic retrospection is characterized by infiltration of retention into protention, appearing in the expression of the melancholic with the constant use of the word 'if'. Thus, it produces a discussion of empty possibilities, protentive acts of a past without any possibilities. They are empty intentions in which retention infiltrates protention, causing confusion. This aspect prevents a true, authentic presentation because retention is depleted. When protention changes, the entire process of melancholia changes, modifying all characteristics of thought flow or continuity, not only temporal though, which makes it even more 
serious and dangerous (Binswanger, 1960/2005). In melancholic prospection the future is seen as lost, impossible, for example, being happy. This goes beyond exacerbated pessimism because one is sure of its effectiveness. The melancholic "knows that foreseen loss in the future is already a reality" (Binswanger, 1960/2005, p.48).

Protention infiltrates into retention on a presumption of a loss of style, a loss of natural experience in which the subject is only an accessory, as in retrospection. Binswanger presents two melancholic domains that "reveal relaxation of intentional structure of temporal objectivity, but also a constituent restructuring of the frame, such as infiltration between retention and protention, in both directions" (Tatossian, 1979/2006, p.160). Despite the disappearance of authentic presentations and the consequent impossibility of true subjects, pseudo-themes and pseudo-contents demonstrate the maintenance of intentional structure. This melancholic trait tends to arouse the temptation to biographical and psychological understandings because there is a direction for oneself or for the world.

Binswanger demonstrates concern in presenting parameters that point to the constitution of the melancholic world. Such an understanding is consistent with the one presented in his later works that are inspired by the genetic phenomenology of Husserl, i.e., the search to find the foundation of the world, in this case, the melancholic world.

\section{Hubertus Tellenbach: The notion of endon and typus melancholicus}

Hubertus Tellenbach, German psychiatrist, born in Cologne in 1914, was professor of psychiatry in the mid-1950s at the University of Heidelberg (Dorr, 1996). Throughout his work, Tellenbach constantly refers to Husserl and Heidegger's philosophy, combining the contributions of both as important resources to explain his clinical experience (Dastur, 2005). In 1961, Tellenbach published his major work entitled "Melancholia". The aim was to conduct a study that privileged the genesis of the melancholic problem based on an endogenous perspective of psychopathology (Ambrosini, Stanghellini, \& Langer, 2011; Dorr, 1996). It was a time when the problem of etiology of mental disorders still remained present throughout the psychiatric tradition and in an attempt to solve it, psychiatry distinguished three causal fields: the somatogenic, psychogenic, and endogenous factors (Tellenbach, 1969/1999). The first two are related to somatic and psychic aspects, while the third is related to the etiological field of endon changes, a concept that is not clear in Psychiatry (Pereira, 1999).

The existence or not of a disposition for mental illness is one of the great discussions in psychopathology. From the perspective proposed by Tellenbach (1969/1999), this disposition is not directly related to somatic and biological nature, nor is it a pure reflection on the individual existence of the human being. Thus, the aim of his study is to understand the origin and movements of endogenous processes, particularly regarding melancholic disorders. Tellenbach's concept of Typus melancholicus emerged when working with 119 patients who had been in a melancholic state and were treated at the psychiatric clinic of the University of Heidelberg. With this study, Tellenbach identified the main personality traits that characterize the specific way of being and that gravitate around the possible development of melancholia (Ambrosini et al., 2011; Von Gebsattel, 1976).

Tellenbach's claim was not to develop a type based on nosological and classification principles of traditional psychiatry, but his contribution comes from the phenomenological thought that prioritizes movement and experience, surpassing the situational relationship of cause and effect. The description of the melancholic type is only possible because endon contains almost constant, fundamental features to understand the pathogenesis of melancholia. The endon is the movement of living of humans, being the fundamental form of vital succession, which is always changing and is characterized by its constant becoming, which can be exemplified, according to Tatossian (1979), by the rhythmic changes of human life as the changes between sleep and wakefulness, the periodicity of the female cycle, regular emergency 
of hunger, thirst, sexual drive and mood swings throughout monthly or even yearly periods.

Tellenbach (1969/1999) does not present a typological proposal of static conceptions and his notion of type was developed based on his immediate clinical experience with individuals who claimed to be melancholic.

We have found essential traits of the melancholic type not through the analysis of properties and their systematic structure, but by experience in encountering those who have been melancholic. The fundamental traits we learn, which are constantly becoming true, are of a structural nature, while certain modes of being are definitively predesigned (Tellenbach, 1969/1999, p.172).

The first striking characteristic of the melancholic type is "orderliness", which, in accordance with Tellenbach (1969/1999), is its main feature. At this point, intense stiffening of the activities of the melancholic type occurs, through regulated narrowing of their personal relationships. These characteristics have a certain obsessive denotation because attachment to order, excessive principles, conscience of duty and thoroughness, repudiating any evidence of improvisation is prominent. Many of these characteristics are required and valued in the Western capitalist world (Leite \& Moreira, 2009). The difference, for the melancholic type, is the lack of elasticity when performing duties because, for the melancholic, the key is in the activity itself and not in the action. People with this type of personality tend to be culturally valued, but suffer unduly for functioning this way. In addition to these features, a lively sense of guilt is evident in view of the events of life and a great need to please others.

The second striking characteristic of the melancholic type is the need for defined limits, which influences, above all, their inter-human relationships that can be experienced in two ways: the being-for-others and being-for-oneself (Tellenbach, 1969/1999). In the first case, the melancholic type cannot remain in debt or owning to another person, tending to live an almost

112 symbiotic way of life by having no aptitude for solitude. Their self-consciousness is fundamentally the being-for-others, and also the made-for-others, particularly regarding an acquaintance. When one fails to completely satisfy the other, either by aging, illness, weddings, etc., there may be significant problems due to the existential sensation of emptiness that can lead to a gravitational field of melancholy (Tatossian, 1975; Tellenbach, 1969/ 1999). The second case, in regard to the relationship with oneself, is marked by a specific attitude of scrupulosity. These people have a high level of moral consciousness, which assumes prohibitive function before almost everything. When failing to deal with feelings of guilt, they try to avoid it as much as possible, imposing on oneself an expiatory behavior (Tellenbach, 1969/1999). It may occur that the high demanding standards concerning the performance of activities tend to cancel its fulfillment, which denotes notorious intolerance with oneself.

Tellenbach (1969/1999) also considers melancholy as endogenous psychosis in which the vital movements happen more slowly as opposed to states of happiness, which occurs much faster. Vital sadness that permeates the melancholic is so long that it borders stagnation of being, inhibiting their basic vital movement. In such rhythmic variations, another characteristic present in endogenous changes is related to the appearance of psychosis at specific times in the development and maturation of people, such as hebephrenia, psychoses of involution and pre-senile psychoses. In these cases, a solely biological or psychological analysis is not sufficient for a comprehensive understanding of the phenomena because the characteristics of both these aspects have a metapsychological and metabiological instance of endon, referring to the completeness of man.

The importance of considering the endogenous aspects lies precisely in the dialectical movement that manifests itself in the interrelation of endon with existence, pointing out that the psychopathological aspects are not limited to those inherited, such as the somatic and biological traits, or simply a psychological trait, but the role of these aspects is not denied. The role of endogeneity to the understanding of mental disorders, particularly 
melancholy, emphasizes the importance of Tellenbach for phenomenological psychopathology. The global character presented by the endogenous aspects that marks the point and the precise moment when the transformation of melancholic subjectivity occurs, is an important step toward developing dynamic and genetic phenomenology, which prioritizes the experience of the subject.

\section{Arthur Tatossian: The possible conditions of the lived depressed and the experience of depressiveness}

The French psychiatrist Arthur Tatossian, 1929-1995, is currently considered one of the leading researchers in contemporary phenomenological psychopathology. He deeply understood the work and was influenced by Husserl, Heidegger, MerleauPonty, Sartre and Scheler, representatives of philosophical phenomenology, as well as the work of Binswanger, Minkowski, Tellenbach, Kimura, among others, important icons of psychiatry and phenomenological psychopathology (Tatossian \& Samuelian, 2006).

Throughout his work, Tatossian published four articles on depression, "Phénoménologie de la depression" (Tatossian, 1975), "Le sens de la depression" (Tatossian, 1977), "Phénoménologie de la depression" (Tatossian, 1981), the same title as the former article, and "Dépression, vécu dépressif et orientation thérapeutique" (Tatossian, 1983); and the book, "La vie en faute de mieux" (Tatossian, 1984), are specific works about depression. In part $C$ in his main book, "La Phénoménologie des Psychoses" Tatossian (1979/2006), critically discusses melancholy and mania based on several phenomenological psychopathology authors, particularly the works of Minkowski, Binswanger and Tellenbach. During his work, Tatossian points out that phenomenology of depression is far from being understood, that it is directly associated with the historical development of phenomenological psychopathology itself and the different ways that the lived depressed are understood. He assumes that the experience of depression should not be restricted to the question of temporality. In this regard, he points out the phenomenological categories of time, body, space and the relationship with others as possible conditions of the lived depressed.

Concerning time, the weight of the past and poor or no prospects for the future, in an empty present, are elements that comprise the experience of stagnation of time lived. It is a constituent of time and, at the same time, constitute also. According to Tatossian (1979/2006, 1983), in melancholy, recognized as a more severe form of depression, the melancholic slows down and lived time stagnates, losing the usual sync with the world. The future is seen as lost or even barred as a possibility. Capacity for action is restricted, as it depends on the future. Without it, one ends up living an empty present, always attracted to the shadow of the past.

Understanding the lived depressed based on the body, Tatossian $(1982,1983)$ returns to the distinction between body-subject, body-that-I-am, and body-object, body-l-have, in accordance with Gabriel Marcel and Maurice Merleau Ponty. The body-object is different from totality and it can be established as an interface with the world, enabling inter-subjectivity, concreteness of a body that can see and be seen, perceived and be perceived. The body-subject denotes the lived experience of the body itself, allowing the body to be recognized as itself.

In a healthy functioning person, there is a balance between the body-subject and body-object. In the case of depression, Tatossian (1983) considers that one only identifies the body-subject, as if the body-object were erased, thus losing the part that intermediates the world. Having no connection, simple acts become difficult, experiencing a paradox. On the one hand, the body is extremely heavy, stuck where it is and incapable of projection. On the other, it is suspended in the air for not having anchorage or support in the world.

Space tends to be experienced as desperately empty, dull, flat and without perspective, reaching a critical level. Despite the difficulty of clinical expression, Tatossian discusses the issue of space as spatial, a possibility for expansion and opening of possibilities. The depressed loses existential 
proximity with things. Distancing is experienced as loss of spatial depth and things become "dull and flat as if everything is out of reach, living as static objects; not integrated into a 'landscape', occupying 'places' and not 'regions'" (Tatossian, 1979/2006, p.134). The depressed lives in a confined, closed space, without any possibilities.

Regarding the lived depressed of others, Tatossian (1983) understands that the depressed experiences a blockage of vital communication with the world, which would be the "background of all true depression" (p.285). This aspect involves the disappearance or shuddering of basal confidence that affects behavior and everyday interaction. It is something primitive, referring to vital communication between human beings and the world. Tatossian distinguishes the lived depressed of others among those who experience sadness, depression and melancholy. In sadness, one fully perceives the existence of the other, which can be of assistance in times of sadness. In depression, the relationship is changed, but there is still the other one as a possibility. It is as if one lived trapped in one's own body or as if there was kind of glass separating one's body. Whereas in melancholia, the possibility of a relationship disappears, the other does not exist as a person, there is noticeable distance, e.g., in the absence of reciprocity of looks (Tatossian, 1983).

Another important contribution of Tatossian is related to the experience of depressiveness, not as a static model, as a form of the lived depressed, but rather an understanding that we can place in the intersection of empiricism of experience that shows, above all, in clinical practice and theory, an a priori understanding developed to understand psychopathology.

Using the case of Blankenburg as an example to illustrate this understanding, Tatossian (1979/2006) tells us of the impossibility to assert that a patient is depressed without first knowing what depressiveness is and, at the same time, it is only possible to know what depressiveness is from the experience and perspective of the patient or others. Although prior knowledge about what is the experience of depressiveness does not mean experience that will be given. Tatossian always considers an upcoming experience to define depressiveness as a hypothesis, a possibility that will only be given from the experience. There is co-experience when encountering the depressed because one experiences the depressed, but also what is depressiveness, i.e., "our experience with the subject and depressiveness" (Tatossian, 1979/2006, p.115), the co-experience of the encounter with the subject and pathology occurs.

In the clinical phenomenological model developed by Tatossian, it is not about staying with the person. But this does not mean to focus only on the accurate diagnosis to seek cure. It is working ambiguously, at the intersection of the theory of phenomenological psychopathology, which seeks to understand the lived depressed and develops knowledge about and experiences depressiveness with clinical practice, where each patient, although diagnosed or presenting similar symptoms, is a unique person. Although the term depressiveness, proposed by Tatossian, does not exist in Portuguese, it describes depression, but without exhausting it, not only because it is not possible, but because depression occurs in the subject and only he/she can talk about it.

\section{Final Considerations}

Inspired by philosophical phenomenology, Minkowski, Binswanger, Tellenbach and Tatossian present different perspectives on the understanding of depression, although there are convergences. The changes in the lived time, for example, are a striking feature evidenced by all these authors, particularly by Minkowski and Binswanger. This aspect goes back to the beginning of phenomenological psychopathology in which the trajectory undertaken to understand melancholy was temporality. We believe that present the contributions of these authors for the phenomenology of depression is an important contribution to clinical practice as it provides tools for understanding the lived world of patients with depression. It is not about establishing a definite diagnosis based on symptoms, but rather the understanding of the existential movement of 
the patient who tends to facilitate clinical contact and the relationship that is established. In their conceptions and different practices, Minkowski, Binswanger, Tellenbach and Tatossian advocate the importance of effective contact with patients and emphasize the return to phenomenological experience as a starting point. That is, thinking about phenomenology of depression, the clinical dimension and the different possibilities will always be present and it is possible to (re)think the lived depressed in view of what the patient presents.

Phenomenological psychopathology endeavors to understand the experience lived and its psychopathological dimensions, loss of existential movement and the crystallization of the single possible experience is illness, such as depression. The authors discussed in the article have significantly contributed to the awareness of the return to experience and understanding of its meanings in the world, carrying out a phenomenology of depression that is predominantly based on their clinical work and research. Phenomenological psychopathology, since its development, intersects with clinical experience, which makes it possible, effective, and critical when undertaking an open position and questioning the experience of the patient and reconsidering the discourse on the illness processes. This prioritization of experience enables phenomenology of depression to be marked by an opening of dialogue between theory and practice.

In this process, Minkowski stands out for his consistency in discussing the time lived in melancholy and he states the conditions for phenomenologicalstructural psychopathology. Binswanger, based on temporality, discusses how it is to be in the world of the melancholic: melancholic retrospection and prospection. Tellenbach, based on clinical practice, develops the notion of Typus, far from the nosological and classification framework that allows us to understand depression as governed by certain traits and that is associated with the patient's world. Finally, Tatossian expands the discussion of depression to other phenomenological categories of existence and develops the notion of depressiveness, an important warning for not theorizing and closing experience in movement. These are different contributions that approach the phenomenological nature, pointing to the incompleteness of experience and the constant search for understanding the lived depressed.

\section{Contributors}

All authors contributed to the conception, study design and final editing of the article.

\section{References}

Abreu e Silva, N. N. (2004). A atualidade da obra de Eugène Minkowski (1985-1972). Boletim Academia Paulista de Psicologia, 24(2), 50-62.

Ambrosini, A., Stanghellini, G., \& Langer, Á. I. (2011). El typus melancholicus de tellenbach en la actualidad: una revisión sobre la personalidad premórbida vulnerable a la melancolía. Actas Españolas de Psiquiatría, 39(5), 302-311.

Binswanger, L. (2005). Mélancolie et manie: etudes phénoménologiques. Paris: Presses Universitaires de France. (Publié à I'origine en 1960).

Cardinalli, I. E. (2012). Daseinsanalyse e esquizofrenia: um estudo da obra de Medard Boss. São Paulo: Escuta.

Dastur, F. (2005). O que é a daseinsanálise? Covilhã: Lusosofia Press.

Dorr, O. (1996). Hubertus Tellenbach, psiquiatra y humanista. In O. Dorr. Espacio y tiempo vividos: estudios de antropología psiquiátrica (pp.187-191). Santiago de Chile: Editorial Universitaria.

Fédida, P. (1970). Préface. In L. Binswanger. Analyse existentielle et psychanalyse freudienne: discours, parcours et Freud. Paris: Gallimard.

Huygens, A. (2011). De la psychanalyse à l'analyse du Dasein: au-delà d'un passage, un saut. In L. Binswanger. Philosophie, anthropologie clinique, daseinsanalyse (pp.269-287). Argenteuil: Le Cercle Herméneutique Editeur.

Jaspers, K. (1987). Psicopatologia geral. Rio de Janeiro: Atheneu. (Originalmente publicado em 1913).

Lehfeld, B. (2011). Le premier Binswanger. In L. Binswanger. Philosophie, anthropologie clinique, daseinsanalyse (pp.37-61). Argenteuil: Le Cercle Herméneutique Editeur.

Leite, M. E., \& Moreira, V. (2009). A contribuição de Tellenbach e Tatossian para uma compreensão fenomenológica da depressão. Arquivos Brasileiros de Psicologia, 61(3), 46-56. 
Martins, F. (1999). O que é pathos? Revista Latino-Americana de Psicopatologia Fundamental, 2(4), 62-80.

Minkowski, E. (1995). Le temps vécu. Paris: Presses Universitaires de France. (Publié à l'origine en 1933).

Moreira, V. (2002). Fundamentos para uma psicopatologia crítica. In V. Moreira \& T. Sloan. Personalidade, ideologia e psicopatologia crítica (pp.109-133). São Paulo: Escuta.

Moreira, V. (2011). A contribuição de Jaspers, Binswanger, Boss e Tatossian para a psicopatologia fenomenológica. Revista da Abordagem Gestáltica, 17(2), 178-190.

Moreira, V., \& Bloc, L. (2012). Fenomenologia do tempo vivido no transtorno bipolar. Psicologia: Teoria e Pesquisa, 28(4), 443-450.

Pélicier, Y. (1995). Vivre le temps: Eugène Minkowski. In E. Minkowski. Le temps vécu (pp.V-XI). Paris: Presses Universitaires de France. (Publié à l'origine en 1933).

Pereira, M. E. C. (1999). De uma heterogeneidade nãofatalista: o endógeno e o Typus melancolicus, segundo Tellenbach. Revista Latinoamericana de Psicopatologia Fundamental, 2(4), 159-163.

Pereira, M. E. C. (2000). Minkowski ou a psicopatologia como psicologia do pathos humano. Revista Latino-Americana de Psicopatologia Fundamental, 3(4), 153-155.

Pessotti, I. (2006). Sobre a teoria da loucura do século XX. Temas em Psicologia, 14(2), 113-123.

Pita, J., \& Moreira, V. (2013). As fases do pensamento fenomenológico de Ludwig Binswanger. Psicologia em Estudo, 18(4), 679-687.

Rodrigues, A. C. T. (2005). Karl Jaspers e a abordagem fenomenológica em psicopatologia. Revista Latinoamericana de Psicopatologia Fundamental, 3(4), 754-768.

Schneider, D. (2009). Caminhos históricos e epistemológicos da psicologia: contribuição da fenomenologia e existencialismo. Cadernos Brasileiros de Saúde Mental, 1(2), 62-76.
Tatossian, A. (1975). Phénoménologie de la dépression. Psychiatries, 21, 77-85.

Tatossian, A. (1977). Le sens de la dépression. Méditerranée Médical, 5(146), 33-36.

Tatossian, A. (1979). Aspects phénoménologiques du temps humain en psychiatrie. Colloque de Vézelay, juin 1977. In Y. Pelicier (Ed.), La folie, le temps, la folie (pp.111-142). Paris: Union Générale d'édition.

Tatossian, A. (1981). Phénoménologie de la dépression. Encéphale, 7, 361-66.

Tatossian, A. (1982). Phénoménologie du corps. In E. Jeddi. Le corps en psychiatrie (pp.99-103). Paris: Masson.

Tatossian, A. (1983). Dépression, vécu dépressif et orientation thérapeutique. In Collectif (Ed.), La maladie depressive (pp.277-293). Paris: Ciba.

Tatossian, A. (1984). La vie en faute de mieux. Les déprimés. Marseille: Mediprint.

Tatossian, A. (2006). A fenomenologia das psicoses. São Paulo: Escuta. (Originalmente publicado em 1979).

Tatossian, J., \& Samuelian, J. C. (2006). Pósfacio da segunda edição francesa. In A. Tatossian. Fenomenologia das psicoses (pp.347-357). São Paulo: Escuta.

Tellenbach, H. (1999). A endogeneidade como origem da melancolia e do tipo melancólico. Revista Latinoamericana de Psicopatologia Fundamental, 2(4), 164-175. (Originalmente publicado em 1969).

Von Gebsattel, F. V. E. (1976). Introduccion. In H. Tellenbach. Melancolía (pp.13-16). Madrid: Ediciones Morata.

World Health Organization. (2012). La depresión: una crisis mundial. Genebra: Author.

Received: February 19, 2014

Final version: January 28, 2015

Approved: April 7, 2015

\section{ERRATA}

Na página 107, Onde se lia:

Lucas BLOC $1,2,3$

Camila SOUZA ${ }^{1}$

Virginia MOREIRA ${ }^{4}$

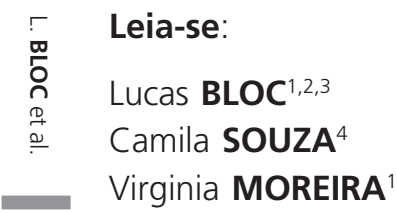

